\title{
COMPOSITIONAL AND THERMAL DIFFERENCES BETWEEN LITHOSPHERIC AND ASTHENOSPHERIC MANTLE AND THEIR INFLUENCE ON CONTINENTAL DELAMINATION
}

\author{
A. I. Kiselev, A. V. Ivanov, B. S. Danilov \\ Institute of the Earth's Crust, Siberian Branch of RAS, Irkutsk, Russia
}

\begin{abstract}
The lower part of lithosphere in collisional orogens may delaminate due to density inversion between the asthenosphere and the cold thickened lithospheric mantle. Generally, standard delamination models have neglected density changes within the crust and the lithospheric mantle, which occur due to phase transitions and compositional variations upon changes of P-T parameters. Our attention is focused on effects of phase and density changes that may be very important and even dominant when compared with the effect of a simple change of the thermal mantle structure. The paper presents the results of numerical modeling for eclogitization of basalts of the lower crust as well as phase composition changes and density of underlying peridotite resulted from tectonic thickening of the lithosphere and its foundering into the asthenosphere. As the thickness of the lower crust increases, the mafic granulite (basalt) passes into eclogite, and density inversion occurs at the accepted crust-mantle boundary ( $\mathrm{P}=20 \mathrm{kbar})$ because the newly formed eclogite is heavier than the underlying peridotite by $6 \%$ (abyssal peridotite, according to [Boyd, 1989]). The density difference is a potential energy for delamination of the eclogitic portion of the crust. According to the model, $\mathrm{P}=70 \mathrm{kbar}$ and $\mathrm{T}=1300{ }^{\circ} \mathrm{C}$ correspond to conditions at the lower boundary of the lithosphere. Assuming the temperature adiabatic distribution within the asthenosphere, its value at the given parameters ranges from $1350{ }^{\circ} \mathrm{C}$ to $1400{ }^{\circ} \mathrm{C}$. Density inversion at dry conditions occurs with the identical lithospheric and asthenospheric compositions at the expense of the temperature difference at $100{ }^{\circ} \mathrm{C}$ with the density difference of only $0.0022 \%$. Differences of two other asthenospheric compositions (primitive mantle, and lherzolite $\mathrm{KH}$ ) as compared to the lithosphere (abyssal peridotite) are not compensated for by a higher temperature. The asthenospheric density is higher than that of the lithospheric base. Density inversion occurs if one assumes the presence of the asthenosphereic material in the composition similar to that of the primitive mantle or lherzolite $\mathrm{KH}$ in amounts no less than 1.40 and 0.83 wt. \%, respectively, of the conventionally neutral fluid. This amount of the fluid seems to be overestimated and thus does not fully correlate with the current estimates of the fluid content in the mantle. Therefore, the most appropriate material for delamination of the thickened lithosphere is only the fluid-bearing asthenosphere which composition corresponds to that of the depleted mantle of middle-ocean ridges (DMM) being the reservoir existing from the Precambrian. In our model, abyssal peridotite is most similar to DMM as compared with other more fertile compositions of the lithosphere. Heat advection due to uplift of fluid-bearing plumes that occurred much time after collisional events may initiate repeated delamination of gravitationally instable parts of the orogenic and cratonic lithosphere.
\end{abstract}

Key words: delamination, lithosphere, asthenosphere, collisional orogen, craton, eclogites.

Recommended by S.I. Sherman

For citation: Kiselev A.I., Ivanov A.V., Danilov B.S. 2015. Compositional and thermal differences between lithospheric and asthenospheric mantle and their influence on continental delamination. Geodynamics \& Tectonophysics 6 (2), 255-265. doi:10.5800/GT-2015-6-2-0180. 


\title{
ВЕЩЕСТВЕННЫЕ И ТЕРМАЛЬНЫЕ РАЗЛИЧИЯ МЕЖДУ ЛИТОСФЕРНОЙ И АСТЕНОСФЕРНОЙ МАНТИЕЙ И ИХ ВЛИЯНИЕ НА КОНТИНЕНТАЛЬНУЮ ДЕЛАМИНАЦИЮ
}

\author{
А. И. Киселев, А. В. Иванов, Б. С. Данилов
}

Институт земной коры СО РАН, Иркутск, Россия

\begin{abstract}
Аннотация: В коллизионных орогенах нижняя часть литосферы может отслаиваться (деламинировать) из-за возникшей инверсии плотностей между астеносферой и более холодной утолщенной литосферной мантией. Обычно в моделях деламинации не рассматриваются плотностные изменения в коре и литосферной мантии, обусловленные фазовыми переходами и вариациями минерального состава при изменении Р-Т условий. Мы акцентируем внимание на том , что эти эффекты могут быть очень важными, возможно преобладающими, по отношению к эффекту простого изменения термальной структуры мантии. В статье изложены результаты численного моделирования с помощью программного комплекса «Селектор» эклогитизации базальтов нижней коры, а также изменения фазового состава и плотности нижележащего перидотита, обусловленных тектоническим утолщением литосферы и ее погружением в астеносферу. Для нижней коры с увеличением глубинности основные гранулиты (базальты) переходят в эклогиты, При этом на принятой границе - корамантия (P=20 кбар) отмечается инверсия плотностей, так как новообразованный эклогит на $6 \%$ тяжелее нижележащего перидотита (абиссального перидотита по Ф. Бойду). Разница в плотностях является потенциальной энергией деламинации эклогитовой части коры. По условиям моделирования нижней границе литосферы соответствуют $\mathrm{P}=70$ кбар и $\mathrm{T}=1300{ }^{\circ} \mathrm{C}$. Принимая адиабатическое распределение температуры в астеносфере, ее значение при данных параметрах оценивается в пределах 1350-1400 ${ }^{\circ} \mathrm{C}$. Инверсия плотности в сухих условиях достигается только при изохимичности составов литосферы и астеносферы за счет перепада температур в $100{ }^{\circ} \mathrm{C}$. Однако разница в плотностях при этом составляет всего $0.0022 \%$. Вещественные различия двух других модельных составов астеносферы (примитивная мантия, лерцолит КН) по отношению к литосфере (абиссальному перидотиту) не компенсируются более высокой температурой. Плотность астеносферы получается более высокой, чем плотность низов литосферы. Инверсия плотностей достигается, если допустить присутствие в составе астеносферы, аналогичном примитивной мантии, или лерцолиту КН, соответственно, не менее 1.40 и 0.83 мас. \% условно нейтрального флюида. Такое количество флюида явно завышено и совершенно не согласуется с современными оценками содержания флюидов в мантии. Следовательно, только флюидсодержащая астеносфера, отвечающая составу деплетированной мантии срединно-океанических хребтов (DMM) - резервуару, существующему с докембрия, - является наиболее подходящей средой для деламинации утолщенной литосферы. В настоящей модели абиссальный перидотит ближе всего соответствует ДММ по отношению к другим более фертильным составам астеносферы. Адвекция тепла, связанная с подъемом флюидосодержащих плюмов, далеко отстоящих по времени от коллизионных событий, также может вызывать гравитационную нестабильность орогенной и кратонной литосферы и ее деламинацию.
\end{abstract}

Ключевые слова: деламинация, литосфера, астеносфера, коллизионный ороген, кратон, эклогиты.

\section{INTRODUCTION}

Mechanical exfoliation and removal of lower parts of the mantle lithosphere are typically termed as delamination, no matter which mechanism they result from. The term 'delamination' was introduced by P. Bird [1979] who used it to describe how the lithospheric mantle is peeled off from the overlying crust due to uplifting and emplacement of the asthenospheric material between them. In [Houseman et al., 1981], another mechanism was proposed for gravitational (convective) instability of the base of the tectonically thickened lithosphere accompanied by complete or partial separation of its mantle part and its foundering into the as- thenosphere. Another commonly used term is 'mantle unrooting' [Marotta et al., 1998].

Fairly recently, delamination has been referred to as an alternative explanation for rapid regional uplift and extension, accompanied by lithospheric thinning and increased magmatic production within mobile belts [Peccerillo, Lustrino, 2005]. Delamination involves an abrupt separation and rapid foundering of the lower tectonically thickened lithosphere into the asthenospheric mantle due to density inversion at the postcollisional stage. A potential energy that drives this process is released as the hot low-density asthenospheric mantle replaces the separated part of the cold dense lithosphere and interacts with its remaining 
thinned part. Thermal and mechanical effects of the asthenosphere on lithosphere thinned by delamination is considered as a main cause of post-collisional magmatism, including batholith formation within mobile belts which undergone strong tectonic thickening during the collision. The purpose of the present discussion is to study by means of numerical modeling the effect of compositional differences between the lithosphere and the asthenosphere as well as the phase transition for possibilities of mechanical destruction of the lower lithosphere after its tectonic thickening. Some consequences of delamination in terms of structure and composition are discussed.

\section{PHYSICAL AND CHEMICAL BASIS FOR DELAMINATION FOR THE LOWER CONTINENTAL LITHOSPHERE}

The lithosphere is usually considered as the strong mobile surface layer resistant to the high tangent (up to $1 \mathrm{kbar}$ ) tension, despite the less strong underlying asthenosphere. It should be emphasized that the definition of the lithosphere relies on rheological characteristics, but does not take into account the composition that changes laterally from continents to oceans especially at the crustal level. In the context of rheology, the lithosphere is a bilayer. The upper mechanical boundary layer (MBL) possess properties of an elastic rigid body exposed to fragile destruction [Anderson, 1994]. A thermal boundary layer (TBL) is situated below the isotherm of $650 \pm 100{ }^{\circ} \mathrm{C}$; within its limits, the lithosphere behaves as a viscous (fragile-elastic) fluid capable to flow but transferring deep-seated heat by conduction from depths where the temperature is close to the temperature of solidus of mantle rocks. The lifetime of TBL depends on its growth rate and viscosity. Its own weight is a cause of its instability. If TBL occurs at a plume side or it thickens in orogenic belts, it became instable. The lower part of TBL cannot resist high stresses and remains bounded with the mechanical boundary layer during a long period of time. The continental lithosphere is destroyed by partial or complete separation of TBL due to its convective instability resulting from quick thickening, and such destruction is defined as 'thermal thinning' [Houseman et al., 1981] analogous to 'delamination'.

According to evaluations of the surface heat flow and the available seismological and thermodynamic data, the oceanic lithosphere thickness ranges from 75 to $100 \mathrm{~km}$, and the continental lithosphere thickness amounts to $200+\mathrm{km}$.

Stabilization of the lithosphere is determined not only by simple cooling of the mantle substance but its chemical stratification. A newly formed oceanic crust is hot and thin in zones of spreading. Changes of the lithosphere thickness are controlled by dynamics of its heat balance. As the lithosphere moves away from constructive boundaries, its thickness increases due to slow conductive cooling. The lithostatic equilibrium between the lithosphere and the asthenosphere is governed by partial melting of the ascending asthenospheric matter at the boundary between plates and differential moving of melting and solid phases. Upon removal of the basaltic liquid from the asthenospheric peridotitic substrate, its density decreases due to the loss of the iron part, while the solidus temperature increases. However, basaltic liquid extraction cools the asthenospheric mantle; the process which partially compensate the decrease of density [Jordan, 1978].

In general cases, when thermal and compositional parameters determining the mantle lithosphere are combined, the lithosphere density is lower than that of the underlying asthenosphere. However, during compression, the lithosphere becomes denser, thicker and more instable due to its quasithermal 'transition' into the asthenosphere. Under such conditions, the lithosphere may delaminate itself, i.e. it can exfoliate in its lower part but only after a critical amount of reduction determined by the difference between densities of the asthenospheric and lithospheric mantle at specific P-T parameters. A theoretical possibility of the lithosphere excessive density relative to the asthenosphere may be realized in collisional orogens where compressive thickening of the lithosphere is followed by extension. Delamination is crucial in this case.

Together with thickening of the lithosphere, the phase transition of basalt into denser modificationeclogite [Ringwood, Green, 1969] makes a significant contribution to inversion of densities between the lithosphere and the asthenosphere. The low-pressure pyroxene-plagioclase-olivine paragenesis of minerals passes into a high-pressure eclogite composed of pyrope garnet and omphacite. The density of eclogite is similar to or may exceed the density of underlying mantle. Eclogitization may occur both in the lower crust and the lithospheric mantle. If basaltic melts pass into eclogites in the mantle, each $10 \%$ of eclogite will increase its density by $1 \%$ [Kay, Kay, 1993]. The contribution of the lower crust in delamination depends on its density, which determines the direction of movement of the lower crust material. In continental regions with the crust thinner than $45 \mathrm{~km}$, the density of the lower crust of any composition must be lower than that of the mantle. In this case, the crust material can flow (especially in the presence of melt) laterally or towards the surface. Conversely, in the regions where compression results in thickening of the crust to $50 \mathrm{~km}$ and more (up to $70 \mathrm{~km}$ in Tibet), the density of rocks of basaltic composition in the lower crust is increased to higher values at the transition into eclogites and the trend to foundering. According to [Sobolev, Babeyko, 1989], the crust thickness can reach maximum values 
at phase transitions because the rocks of basaltic composition are classified (by their density and seismic velocities) as 'crust' if they are gabbroid in terms of mineralogy, but as 'mantle' if eclogitic. Thus, only the lithospheric mantle is assumed as gaining the negative buoyancy, and the lowest part of the thickened crust (if it is of basaltic composition) also contributes to the negative buoyancy. In regions with the thick crust, when the lithospheric mantle delaminates, the lower part of the crust delaminates also. Thermal thinning without advection of heat as an alternative to delamination is unrealistic since conductive mass transport and radioactive heating are very slow [Yuen, Fleitout, 1985]. Heating and softening of a large volume of the lithospheric mantle for its transition into the asthenosphere are impossible during short-time intervals corresponding to the observed tectonic transformations in the orogenic zones.

\section{NUMERICAL MODELING OF PHASE AND DENSITY CHANGES IN THE CONTINENTAL LITHOSPHERE DURING ITS TECTONIC THICKENING}

Generally, standard delamination models have neglected density changes within the crust and the lithospheric mantle which occur due to phase transitions and compositional variations during tectonic thickening. Our attention is focused on effects of phase and density changes that may be very important and even dominant when compared to effect of a simple change of the thermal mantle structure. This section reports results of numerical modeling of the basaltic lower crust eclogitization as well as changes of phase composition and density of the underlying peridotite, which result from tectonic thickening of the lithosphere and its foundering into the asthenosphere.

Our concept of the delamination model is illustrated in Figure 1 that shows geotherm positions and lithosphere sections before and after lithospheric thickening followed by delamination. Data on accepted model compositions of the lower crust, lithospheric mantle and asthenosphere are given in Table 1. Chemically, the lower crust is presented by quartz tholeiite and alkaline olivine basalt used in the experiments to study the phase transition of basalt into eclogite [Ringwood, Green, 1969]. The composition of abyssal peridotite characterizing of the post-Archean lithosphere [Boyd, 1989] is used in the model as the analogue of the lithospheric mantle. A quantitative determination of the bulk composition of the asthenosphere is indistinct. Thus, the primitive mantle (A1) after [McDonough, 1990] and abyssal peridotite (A3) are accepted as twoside constraints of its composition. Moderately depleted spinel lherzolite from Kilbourne Hole (Mexica) is accepted as the model composition of the astheno-

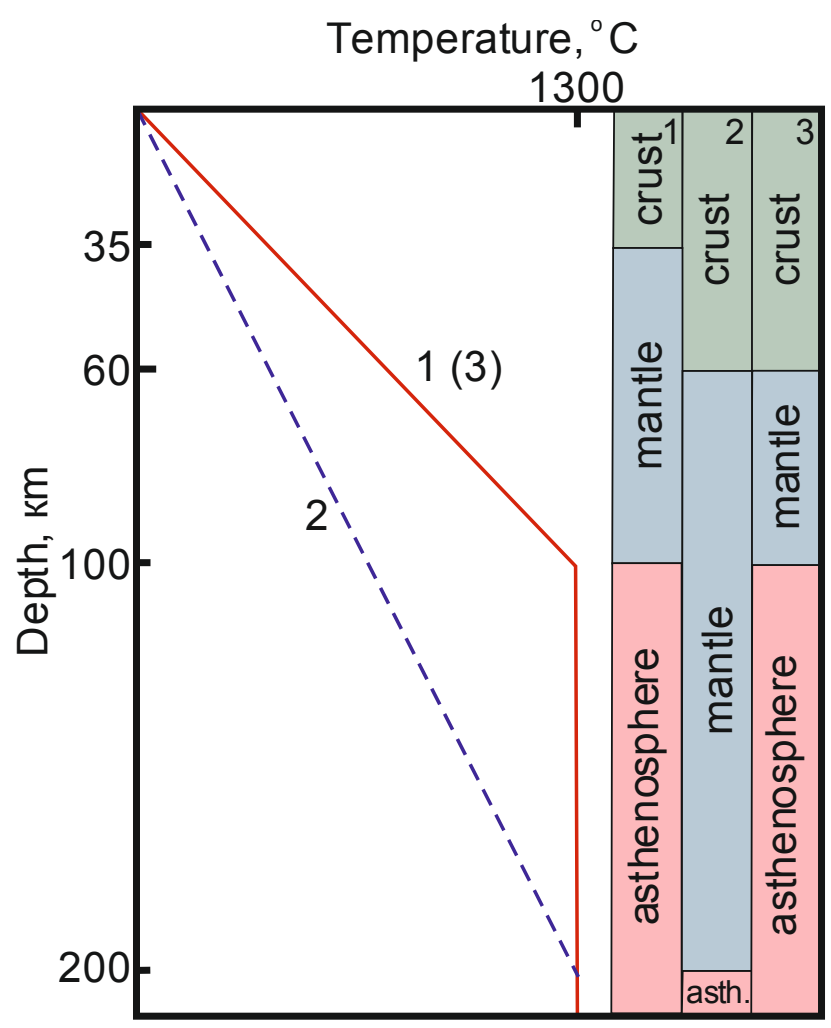

Fig. 1. Lithospheric sections and geotherm positions before and after tectonic thickening followed by delamination. From [England, Houseman, 1989], with minor additions.

Рис. 1. Традиционное отображение литосферных разрезов и положений геотерм до и после тектонического утолщения с последующей деламинацией (по [England, Houseman, 1989], с минимальными дополнениями).

sphere (A2), which is intermediate between compositions of the primitive mantle and abyssal peridotite [Basaltic volcanism..., 1981]. It should be noted that the primitive mantle is the most dense and fertile among possible bulk model compositions of the asthenosphere that is depleted, to a certain degree, in the basaltic component and, most likely, consistent with the asthenosphere of early stages of the mantle evolution in the Early Precambrian.

Besides, there is geological evidence concerning the asthenosphere composition. Some peridotitic orogenic massifs (Lanzo in Italy, Lerz in France and others) are considered as examples of local contacts and the lithosphere-asthenosphere boundary [Menzies et al., 1991]. Within these massifs, unmetasomatized porphyroclastic plagioclase and spinel peridotites, that are compositionally similar to DMM (depleted mantle of the midocean ridges), are assigned to the asthenospheric substance. It is believed that DMM, which fragments are alpinotype ophiolites and abyssal peridotites, represent a global reservoir existing from the Precambrian, 
$\mathrm{T}$ a b l e 1 . Model compositions of the lower crust $(1,2)$, the lithospheric mantle $(3)$, and the asthenosphere $(3,4,5)$

Т а б л и ц а 1. Модельный состав нижней коры $(1,2)$, литосферной мантии $(3)$ и астеносферы $(3,4,5)$

\begin{tabular}{llllll}
\hline Oxides & $\begin{array}{l}\text { Quartz tholeiite poor } \\
\text { in alkaline }\end{array}$ & $\begin{array}{l}\text { Alkaline olivine } \\
\text { basalt }\end{array}$ & $\begin{array}{l}\text { Abyssal peridotite } \\
\text { A3 }\end{array}$ & $\begin{array}{l}\text { Spinel lherzolite } \\
\text { A2 }\end{array}$ & $\begin{array}{l}\text { Primitive mantle } \\
\text { A1 }\end{array}$ \\
\hline & 1 & 2 & 3 & 4 & 5 \\
\hline $\mathrm{SiO}_{2}$ & 49.88 & 45.39 & 43.60 & 44.80 & 44.80 \\
$\mathrm{TiO}_{2}$ & 2.14 & 2.52 & 0.02 & 0.12 & 0.21 \\
$\mathrm{Al}_{2} \mathrm{O}_{3}$ & 13.89 & 14.69 & 1.18 & 3.34 & 0.45 \\
$\mathrm{Fe}_{2} \mathrm{O}_{3}$ & 2.84 & 1.87 & 0.00 & 8.40 \\
$\mathrm{FeO}$ & 9.65 & 12.42 & 8.22 & 0.00 & 37.20 \\
$\mathrm{MgO}$ & 8.48 & 10.37 & 45.20 & 3.60 \\
$\mathrm{CaO}$ & 10.82 & 9.14 & 1.13 & 39.24 & 0.34 \\
$\mathrm{Na} 2 \mathrm{O}$ & 1.84 & 2.62 & 0.02 & 3.14 & 0.03 \\
$\mathrm{~K}_{2} \mathrm{O}$ & 0.08 & 0.78 & 0.00 & 0.03 & 0.03 \\
$\mathrm{P}_{2} \mathrm{O}_{5}$ & 0.22 & 0.02 & 0.00 & 0.01 & 0.14 \\
$\mathrm{MnO}$ & 0.16 & 0.18 & 0.14 & 0.00 & 0.43 \\
$\mathrm{Cr} \mathrm{O}_{3}$ & 00.00 & 0.00 & 0.22 & 0.26 & 0.27 \\
$\mathrm{NiO}$ & 0.00 & 0.00 & 0.00 & 100.07 & 99.89 \\
$\mathrm{Cумма}$ & 100.00 & 100.00 & 99.73 & \\
\hline
\end{tabular}

N o t e. 1-2 - data from [Ringwood, Green, 1969], 3 - [Boyd, 1989], 4 - [Basaltic volcanism..., 1981], 5 - [McDonough, 1990].

П р и м е ч а н и е. 1-2 - [Ringwood, Green, 1969], 3 - [Boyd, 1989], 4 - [Basaltic volcanism..., 1981], 5 - [McDonough, 1990].

of which the asthenosphere forms a part [Menzies, 1989].

The Selector software complex [Karpov et al., 1997] was used for calculations of equilibrated mineral assemblages from the accepted bulk compositions (Table 1) and P-T parameters corresponding to the geotherm characteristic for the tectonically thickened lithosphere (Fig. 2). One of the starting conditions for modeling is that thickening proceeds under isothermal conditions at the constant temperature of the lowermost lithosphere $\left(1300{ }^{\circ} \mathrm{C}\right)$ followed only by the decrease of the temperature gradient in the lithospheric column. In this model, the temperature of the asthenosphere at a depth of $200 \mathrm{~km}$ is $1400{ }^{\circ} \mathrm{C}$, according to the adiabatic gradient about $0.5{ }^{\circ} \mathrm{C} / \mathrm{km}$. Thus, the lithospheric section, including the lower crust and the lithospheric mantle, and the upper asthenosphere represent three thermodynamically closed systems building on each other with the given bulk composition and relevant P-T parameters. Our model aimed at determination of equilibrated mineral assemblages and their densities within the range of pressure and temperature values according to the accepted geotherm (Fig. 2) and the list of probable mineral phases (separately for every system), and, finally, elucidation of probable density inversion in zones of transition from the crust to the lithospheric mantle and from the latter to the asthenosphere.

According to the modeling conditions, the chemical compositions/systems representing the lower crust, the lithospheric mantle and the asthenosphere do not contain any fluid phase and can be described by ten independent components $(\mathrm{Al}, \mathrm{Ca}, \mathrm{Fe}, \mathrm{Mg}, \mathrm{Mn}, \mathrm{K}, \mathrm{Na}, \mathrm{Si}$, $\mathrm{Ti}$, and $\mathrm{O}$ ). A 'neutral' fluid (C-O-H-N) was added to the asthenosphere composition at the final stages of modeling in order to estimate its effect on the density. Intercoordinated data of thermodynamic properties of minerals [Holland, Powell, 1998] were used in the systems for choosing probable dependent components / mineral phases. The chosen phases / minerals are represented by solid solutions in their ideal miscibility and separate components. Below is the list of such solutions (solid solution names are given in italics): $\mathrm{Ol}$ (olivine) - forsterite + fayalite + tephroite; Opx (orthopyroxene) - enstatite + ferrosilite; $\mathrm{Cpx}$ (clinopyroxene) - diopside + hedenbergite + Ca-tschermakite + Mgtschermakite + acmite + leucite; Gr (garnet) - almandine + andradite + grossular + pyrope + spessartine; Sp (spinel) - hercynite + Mg-spinel; Pl (plagioclase) - albite + anortite; Mt (magnetite) - magnetite + magnesioferrite + ulvospinel; Ilm (ilmenite) - ilmenite + geikielite + pyrophanite; And (andalusite); Ky (kyanite); Sil (sillimanite); Cor (corundum); Q (quartz); Crb (cristobalite); Td (tridimite); Co (coesite); St (stishovite); Hm (hematite); Fe (metallic iron); Per (periclase); Ru (rutile).

Volumes of solid solutions components were calculated by the method described in [Holland, Powell, 1998]. The total components volume is equal to the phase volume; therefore, the weight/volume value is the pure rock density. Changes of density with pressure and temperature are related both to phase transitions (spinel-garnet or quartz-coesite type) and redistribution of elements between phases with changes of P-T parameters. Equilibrated assemblages of mineral pha- 


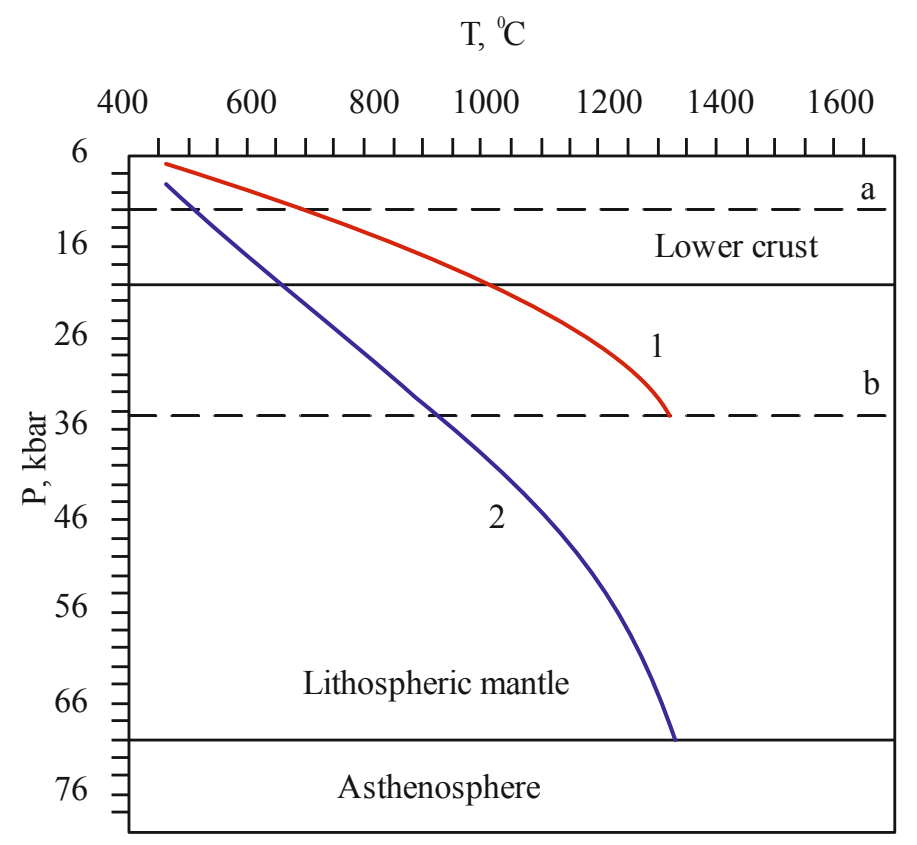

Fig. 2. Geotherms before (1) and after (2) tectonic thickening of the lithosphere.

1 - continental geotherm $\left(50 \mathrm{mWm}^{-2}\right)$, from [Pollack, Chapman, 1977]. 2 - calculated geotherm provided that the temperature was constant at the lithospheric base $\left(1300{ }^{\circ} \mathrm{C}\right)$ before and after thickening. Dotted line show initial positions of the lower crust base (a) and the lithospheric mantle (b).

Рис. 2. Геотермы до (1) и после (2) тектонического утолщения литосферы.

1 - континентальная геотерма (50 мВт/м²), по данным [Pollack, Chapman, 1977]. 2 - рассчитанная геотерма при условии фиксированной температуры $\left(1300{ }^{\circ} \mathrm{C}\right)$ в основании литосферы до и после утолщения. Пунктирными линиями показаны начальные положения основания нижней коры (a) и литосферной мантии (b).

ses, their quantitative composition and density values (Fig. 3) are determined from calculations of equilibrium in the multisystem composed of three systems in the range of $\mathrm{T}=400-1300$ and $1400^{\circ} \mathrm{C}$ and $\mathrm{P}=6-20,20-$ $70,70-75$ kbar. As the thickness of the lower crust increases, the eclogitic paragenesis replaces the granulitic one, and the density increases considerably. A difference between contents of the major elements in the model composition of the lower crust (Table 1) does not significantly impact the density variability of the newly formed eclogites.

Sharp density inversion occurs at the lower crustmantle boundary ( $\mathrm{P}=20 \mathrm{kbar})$, where abyssal peridotite is about $6 \%$ lighter than eclogites. A similar situation occurs in the Kwinling-Dubi orogenic belt where the density of unalterated eclogites of the lower crust amounts to $3.47 \pm 0.04 \mathrm{~g} / \mathrm{sm}^{3}$, i.e. $0.2 \mathrm{~g} / \mathrm{sm}^{3}$ higher than that of peridotitic xenoliths representing the upper mantle of the Eastern China [Gao et al., 1999]. A diffe- rence in the density values mentioned above drives delamination of eclogites and is very important for the evolution of the continental crust and the crust-mantle interaction.

According to the model, the lower lithospheric boundary corresponds to conditions of $\mathrm{P}=70 \mathrm{kbar}$ and $\mathrm{T}=1300{ }^{\circ} \mathrm{C}$. The asthenospheric temperature is $100{ }^{\circ} \mathrm{C}$ higher. This temperature change is conventionally related to 'instantaneous' foundering of the lowermost thickened lithosphere into the hot asthenosphere $\left(\mathrm{T}=1400{ }^{\circ} \mathrm{C}\right)$. The given assumption follows from the relation of the time interval of tectonic, metamorphic and magmatic events in the collisional orogen evolution and the time interval (that is longer) of thermal relaxation of the thickened lithosphere during conductive heat transfer from depth. The calculated asthenospheric density at the boundary zone is higher than that of the lithosphere (Fig. 3, B). This is related to the fact that compositional differences between the model compositions for the lithosphere (A3 - abyssal peridotite) and the asthenosphere (A1 - primitive mantle, A2 - KH lherzolite) are too significant to be compensated by the accepted temperature differences $\left(100{ }^{\circ} \mathrm{C}\right)$ between them. These differences are expressed in different quantities of olivine, garnet, clino- and orthopyroxene contained in the lithospheric mantle and the asthenosphere (Fig. 3, A). Under dry conditions, density inversion due to the temperature difference between the lithosphere and the asthenosphere occurs only if their compositions are similar to each other and comprises $0.0022 \mathrm{wt}$. \%. In this case, density inversion between the asthenosphere represented by A1 and A2 compositions and the lithosphere occurs only if they contain no less than 1.4 and 0.83 wt. \% of the conventionally neutral fluid, respectively (Fig. 4). These values exceed the estimated fluid content in the primitive mantle (0.83 wt. \%, from [Zotov, 1989]). In case when the $30-\mathrm{km}$ eclogitic crust is added to the $170-\mathrm{km}$ peridotitic mantle, density inversion occurs because the lithospheric mantle becomes denser by about $1 \%$.

The available estimates of the fluid content for the entire mantle are uncertain and range between relatively low values from $0.04 \%$ [Dreibus et al., 1997] to $0.1 \%$ for $\mathrm{H}_{2} \mathrm{O}$ [Ringwood, 1966] and $0.83 \%$ for the complex fluid in the primitive mantle [Zotov, 1989]. This suggests that only the fluid (melt)-bearing as thenosphere compatible with the DMM composition is the most appropriate medium for delamination of the tectonically thickened lithosphere. In the proposed model, abyssal peridotite is most closely corresponding to the DMM reservoir. More fertile asthenospheric compositions (lherzolite $\mathrm{KH}$, primitive mantle) can support delamination of the overlying lithosphere only at higher fluid content.

The numerical modeling results suggest, in general, a probability of gravitational instability both at the 
A
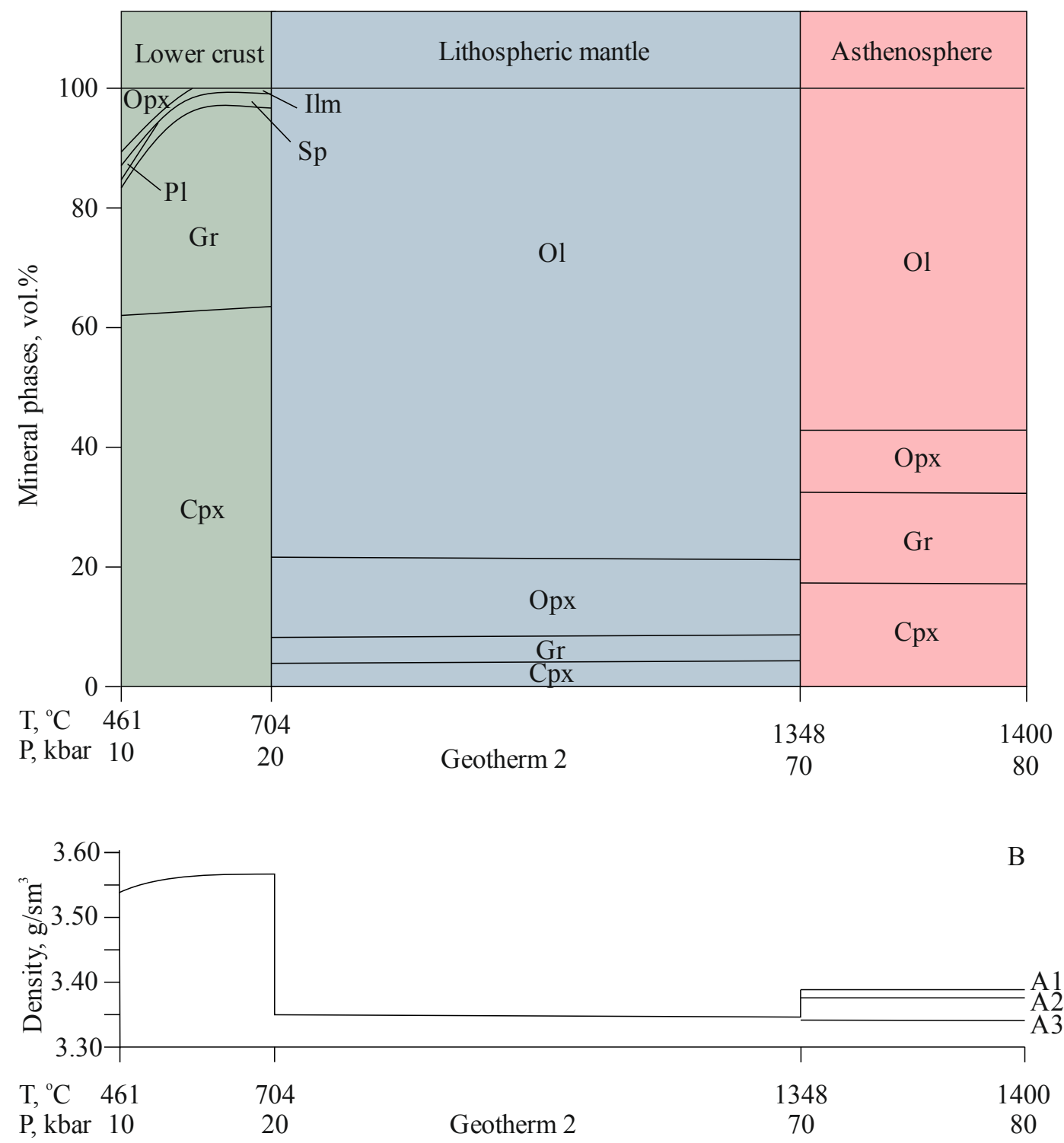

Fig. 3. $A$ - results of calculations of equilibrium mineral assemblages for the lower crust, the lithospheric mantle (A3) and the asthenosphere (A1) after tectonic thickening in accordance with geotherm 2 . $B$ - calculated density and its variations at the boundaries (lower crust - lithospheric mantle - asthenosphere) under dry conditions with different model compositions of the asthenosphere (Table 1, A1, A2, A3).

Рис. 3. $A$ - результаты расчетов равновесных минеральных ассоциаций для нижней коры, литосферной мантии (A3) и астеносферы (A1) после тектонического утолщения в соответствии с геотермой 2. $B$ - рассчитанные плотности коры, литосферной мантии и астеносферы в сухих условиях с различным модельным составом астеносферы (Табл. 1, A1, A2, A3).

lower crust-mantle boundary under dry conditions resulted from eclogitization of the mafic lower crust and the lithosphere-asthenosphere boundary. At the lithospheric-asthenospheric level, delamination under dry condition is possible only if their compositions are almost the same. In other cases, it is necessary to assume the presence of a certain amount of the fluidphase or melt in the asthenosphere, which decreases not only its density, but its viscosity as well.

\section{TECTONIC CONDITIONS FOR DELAMINATION MAGMATISM}

Favorable conditions for delamination occurred within collisional orogens that appeared at regular intervals. Delamination was preceded by lateral shortening and thickening of the crust and the lithosphere. The tectonic increase of the lithospheric thickness after the main stage of deformation was followed by submergence of the lithospheric basement, foundering of 


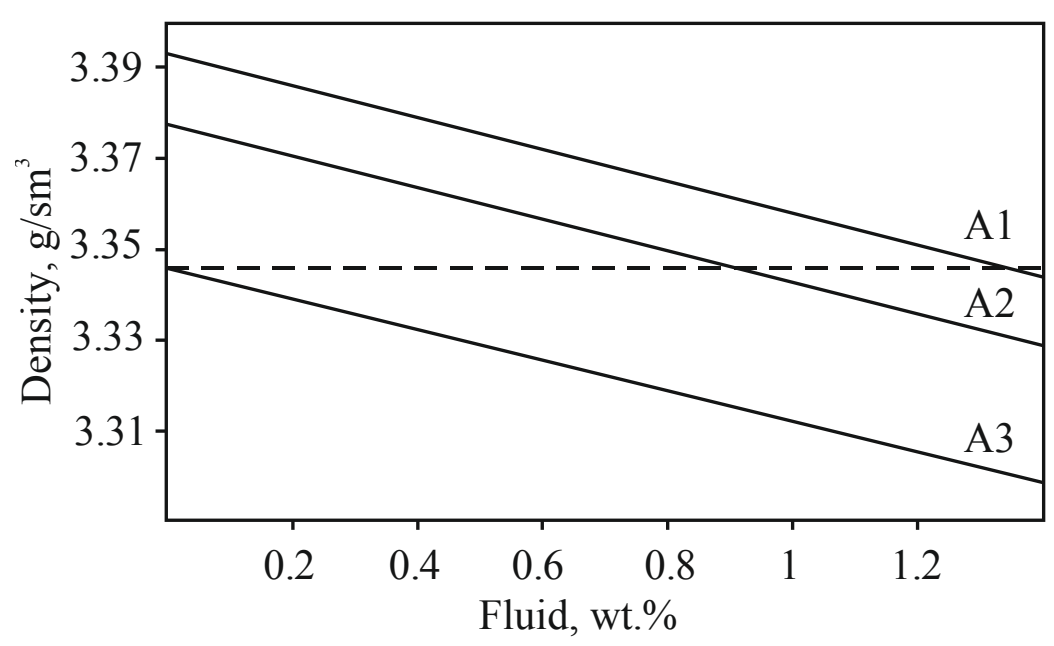

Fig. 4. Density of the model asthenospheric compositions versus their fluid contents (C-O-H-N) at the lithospheric basement $\left(\mathrm{T}=1400{ }^{\circ} \mathrm{C}, \mathrm{P}_{\text {total }}=70 \mathrm{kbar}\right)$. A1 - abyssal peridotite, $\mathrm{A} 2$ - spinel-lherzolite $\mathrm{KH}, \mathrm{A} 3$ - primitive mantle.

Рис. 4. Зависимости плотности модельного астеносферного состава от концентрации флюида (C-O-H-N) в основании литосферы $\left(\mathrm{T}=1600{ }^{\circ} \mathrm{C}, \mathrm{P}_{\text {сумм }}=70\right.$ кбар).

geotherms, and the decrease of the geothermal gradient relative as compared to the initial state. About 130 Ma [Houseman et al., 1981] are required in case of conductive heating for the return of the isotherms to their original positions after the double thickening of the lithosphere at starting lithospheric thickness of 100 $\mathrm{km}$. In reality, however, the double thickening of the lithosphere in zones of continental convergence may occur during 30-50 Ma, which is consistent with the temporal relationship between deformation, metamorphism and magmatism in the intercontinental mobile folded belts. It follows that conductive heating of the thickened lithosphere cannot provide thermal conditions for regional metamorphism and granitic magmatism during 30-50 Ma.

A significant decrease of the lithospheric thickness resulting from delamination furnishes conditions for quick heating of the remaining part of the lithospheric mantle and the lower crust as regards to the thickened lithosphere, which, in its turn, provides for regional metamorphism and melting of the crust. The hot asthenospheric substance is not only a source of heating; it also produces basaltic melts which propagate to the crustal levels heating the crust. Delamination provides conditions for postorogenic extension and uplifting on sites of its manifestation. In collisional orogens, the thickening of the crust prior to delamination (thus increase of pressure of crustal rocks) was followed by metamorphism of the crustal rocks with eclogitic facies in the lowermost crust. Delamination invoked the increase of heat flow, magmatism and postorogenic extension, formation of gently pitching structures of extension with pure shear at deep levels of the crust and simple displacement with detachment at levels of the upper crust. Postdelamination collapse due to exfoliation of the lithospheric root is characterized by extension in the form of transtension and isothermal uplift of the territory. Vertical shortening of the crust thickness during this stage is exemplified by development of subhorizontal gneiss structures with plates of granites intruded in the zone of shearing below of the upper crust extending detachment. Formation of the large volume of granites is synchronous with rapid lithospheric thinning involving weakness of the crust and its extension. Within metamorphic rocks of amphibolite facies, the subhorizontal structures of extension comprise numerous lens-shaped boudins, i.e. remains of the eclogitic facies formations with structures of early subvertical compression indicating the presence of the eclogitic basement of the crust at the stage of its thickening [Dewey, 1995].

Evidence of delamination under the areas that recently underwent tectonic thickening are rapid uplifting and changes in tension field, tangible changes in crustal and mantle magmatism, which reflect changes in thermal and compositional structures of the lithosphere. Criteria that indicate delamination tectonics and magmatism in the Cenozoic are discovered, for example, in the southern Puna Plateau in Central Andes [Kay, Kay, 1993] and the northern Tibetan plateau [Beghoul et al., 1993].

P. Bird [1979] introduced the term 'delamination' to describe the mechanism explaining the formation of the Colorado plateau. The Puna Plateau in Argentina is the most significant example of delamination in the recent past. The presence of a seismic 'window', i.e. the 
lack of earthquakes under this plateau, geochemical peculiarities of mafic lavas within its boundaries (OIBtype) are due to delamination of the continental lithosphere part. The delaminated block comprising the crustal and mantle parts of the lithosphere was involved in the circulating asthenospheric system below the submerging slab. Examples of structural and compositional evidences of delamination in other young orogens are also numerous [Gîrbacea, Frisch, 1998].

It is likely that delamination was more common process during supercontinental accretion. It could be an important element in the mechanism of generation of the sialic crust in the Archean [Rudnik, 1995] as well as shortening of the thick cratonal lithosphere in periods of upwelling of the low-dense hot mantle material to the cratonic basement [O'Reilly et al., 1998; Gao et al., 2009]. Together with subduction, delamination is an important factor contributing to lithospheric recycling [Anderson, 2005]. Recognition of delamination-related magmas may be a unique way to recognize past delamination events, because the magmas when compared with other signatures are the most indelible indicators.

\section{CONCLUSION}

The available geological and geophysical data suggest that in collisional orogens, the lithosphere becomes gravitationally instable and can be delaminated both by removal of the thickened eclogitic portion of the lower crust and by removal of the mantle lithospheric root, in general, resulting from generated density inversion upon tectonic thickening. Generally, the standard delamination models neglect density changes within the crust and the lithospheric mantle which take place due to phase and composition changes while P-T parameters change. These effects may be very important and they are probably dominant when compared with the effect of a simple change of the thermal structure of the mantle.

Conditions of changes of the lithospheric density structure are determined from modeling of eclogitization of the lower crust basalts as well as changes of the phase composition and the density of underlying peridotite caused by tectonic thickening of the lithosphere and its foundering into the asthenosphere. While thickness of the lower crust is increasing, the mafic granulites (basalts) pass into eclogites. In this case, density inversion occurs at the crust-mantle boundary $(\mathrm{P}=20$ kbar) because eclogite is by $6 \%$ heavier than underlying peridotite. The difference in the densities is a driving force for delamination of the eclogitic portion of the crust.

Density inversion at the lithosphere-asthenosphere boundary is accomplished only at equilibrium of their chemical compositions due to the temperature difference of $100{ }^{\circ} \mathrm{C}$, and it is no more than $0.0022 \%$. The compositional difference of two other bulk compositions of the asthenosphere (primitive mantle and lherzolite $\mathrm{KH}$ ) as compared to the lithosphere is not compensated by its higher temperature. The density of asthenosphere is higher than that of the lowermost lithosphere. Density inversion occurs in case of presence of the conventionally neutral multicomponent $(\mathrm{C}-\mathrm{O}-\mathrm{H}-\mathrm{N})$ fluid in amounts of $1.40 \mathrm{wt}$. \% and $0.83 \mathrm{wt}$. \%, respectively, in the primitive mantle and the lherzolite $\mathrm{KH}$ simulating fertile asthenosphere. Consequently, the fluid-bearing asthenosphere corresponding to the composition of the depleted mantle of middle-ocean ridges (DMM) is most suitable for delamination of the lithosphere.

Advection of heat by plumes occurring after collisional events can initiate gravitational instability and delamination of the lowermost lithosphere due to the decrease of the asthenospheric density resulting from the temperature increase and the fluid phase in its composition. This is probably reflected in the tomographic sections of the 'anomalous mantle' of contemporary areas of tectonothermal activity in the form of lateral alterations of relatively high-velocity (cold lithospheric?) and low-velocity (hot asthenospheric) portions of the mantle substance.

\section{REFERENCES}

Anderson D.L., 1994. The sublithospheric mantle as the source of continental flood basalts; the case against the continental lithosphere and plume head reservoirs. Earth and Planetary Science Letters 123 (1), 269-280. http://dx.doi. org/10.1016/0012-821X(94)90273-9.

Anderson D.L., 2005. Large igneous provinces, delamination, and fertile mantle. Elements 1 (5), 271-275. http://dx.doi. org/10.2113/gselements.1.5.271.

Basaltic Volcanism Study Project, 1981. Basaltic Volcanism on the Terrestrial Planets. Pergamon Press, Inc., New York, $1286 \mathrm{p}$.

Beghoul N., Barazangi M., Isacks B.L., 1993. Lithospheric structure of Tibet and western North America: Mechanisms of uplift and a comparative study. Journal of Geophysical Research 98 (B2), 1997-2016. http://dx.doi.org/10.1029/ 92JB02274.

Bird P., 1979. Continental delamination and the Colorado Plateau. Journal of Geophysical Research 84 (B13), 75617571. http://dx.doi.org/10.1029/JB084iB13p07561. 
Boyd F.R., 1989. Compositional distinction between oceanic and cratonic lithosphere. Earth and Planetary Science Letters 96 (1), 15-26. http://dx.doi.org/10.1016/0012-821X(89)90120-9.

Dewey J.F., 1995. The fabrics of orogens. In: Centennial Geocongress, South African Geological Society, Extended Abstracts, vol. 1, p. 291-294.

Dreibus G., Jagoutz E., Wänke H., 1997. Water in the Earth's mantle. Geologiya i Geofizika (Russian Geology and Geophysics) 38 (1), 269-275.

England P., Houseman G., 1989. Extension during continental convergence, with application to the Tibetan Plateau. Journal of Geophysical Research 94 (B12), 17561-17579. http://dx.doi.org/10.1029/JB094iB12p17561.

Gao Sh., Zhang B., Jin Zh., Kern H., 1999. Lower crustal delamination in the Qinling-Dabie orogenic belt. Science in China Series D: Earth Sciences 42 (4), 423-433.

Gao Sh., Zhang J.F., Xu W.L., Liu Y.Sh., 2009. Delamination and destruction of the North China Craton. Chinese Science Bulletin 54 (19), 3367-3378. http://dx.doi.org/10.1007/s11434-009-0395-9.

Gîrbacea R., Frisch W., 1998. Slab in the wrong place: lower lithospheric mantle delamination in the last stage of the Eastern Carpatian subduction retreat. Geology 25 (7), 611-614. http://dx.doi.org/10.1130/0091-7613(1998)026 $<0611$ :SITWPL>2.3.CO;2.

Holland T.J.B., Powell R., 1998. An internally consistent thermodynamic data set for phases of petrological interest. Journal of Metamorphic Geology 16 (3), 309-343. http://dx.doi.org/10.1111/j.1525-1314.1998.00140.x.

Houseman J.A., McKenzie D.P., Molnar P., 1981. Convective instability of a thickened boundary layer and its relevance for the thermal evolution of continental convergent belts. Journal of Geophysical Research 86 (B7), 6115-6132. http://dx.doi.org/10.1029/JB086iB07p06115.

Jordan Th.H., 1978. Composition and development of the continental tectosphere. Nature 274 (5671), 544-548. http://dx.doi.org/10.1038/274544a0.

Karpov I.K., Chudnenko K.V., Kulik D.A., 1997. Modeling chemical mass transfer in geochemical processes; thermodynamic relations, conditions of equilibria and numerical algorithms. American Journal of Science 297 (8), $767-806$. http://dx.doi.org/10.2475/ajs.297.8.767.

Kay R.W., Kay S.M., 1993. Delamination and delamination magmatism. Tectonophysics 219 (1), 177-189. http://dx.doi. org/10.1016/0040-1951(93)90295-U.

Marotta A.M., Fernandez M., Sabadini R., 1998. Mantle unrooting in collisional settings. Tectonophysics 296 (1), $31-46$. http://dx.doi.org/10.1016/S0040-1951(98)00134-6.

McDonough W.F., 1990. Constraints on the composition of the continental lithospheric mantle. Earth and Planetary Science Letters 101 (1), 1-18. http://dx.doi.org/10.1016/0012-821X(90)90119-I.

Menzies M.A., 1989. Cratonic, circumcratonic and oceanic mantle domains beneath the western United States. Journal of Geophysical Research 94 (B6), 7899-7915. http://dx.doi.org/10.1029/JB094iB06p07899.

Menzies M.A., Bodinier J.L., Thirlwall M., Downes H., 1991. Astenosphere-lithosphere relationships within orogenic massifs. In: Proceedings of the Fifth International Kimberlite Conference. Araxá, Brazil, p. 281-284.

O'Reilly S.Y., Griffin W.L., Dyomani Y., 1998. Are lithosphere forever? In: Proceedings of the 7th International Kimberlite Conference. Cape Town, South Africa, p. 646-648.

Peccerillo A., Lustrino M., 2005. Compositional variations of Plio-Quaternary magmatism in circum-Tyrrhenian area deep versus shallow mantle processes. In: G.R. Foulger, J.H. Natland, D.S. Presnall, D.L. Anderson (Eds.), Plates, Plumes and Paradigms. Geological Society of America Special Paper, vol. 338, p. 421-434. http://dx.doi.org/10. 1130/0-8137-2388-4.421.

Pollack H.N., Chapman D.S., 1977. On the regional variation of heat flow, geotherms, and lithospheric thickness. Tectonophysics 38 (3), 279-296. http://dx.doi.org/10.1016/0040-1951(77)90215-3.

Ringwood A.E., 1966. The chemical composition and origin of the Earth. In: P.M. Harley (Ed.), Advances in Earth Science. MIT Press, Cambridge, p. 287-356.

Ringwood A.E., Green D.H., 1969. Phase Transitions. In: P.J. Hart (Ed.), The Earth's Crust and Upper Mantle. AGU Geophysical Monograph Series, vol. 13, p. 637-649. http://dx.doi.org/10.1029/GM013p0637.

Rudnik R.L., 1995. Making continental crust. Nature 378 (6557), 571-577. http://dx.doi.org/10.1038/378571a0.

Sobolev S.V., Babeyko A.Y., 1989. Phase transformations in the lower continental crust and its seismic structure. In: R.F. Mereu, S. Mueller, D.M. Fountain (Eds.), Properties and processes of Earth's lower crust. AGU Geophysical Monograph Series, vol. 51, p. 311-320. http://dx.doi.org/10.1029/GM051p0311.

Yuen D.A., Fleitout L., 1985. Thinning of the lithosphere by small-scale convection destabilization. Nature 313 (5998), 125-128. http://dx.doi.org/10.1038/313125a0.

Zotov I.A., 1989. About sources of the transmagmatic fluids. In: Physico-chemical analysis of mineral generation. Nauka, Moscow, p. 38-45 (in Russian) [Зотов И.А. К проблеме источника трансмагматических флюидов // Физико-химический анализ процессов минералообразования. М.: Наука, 1989. С. 38-45]. 

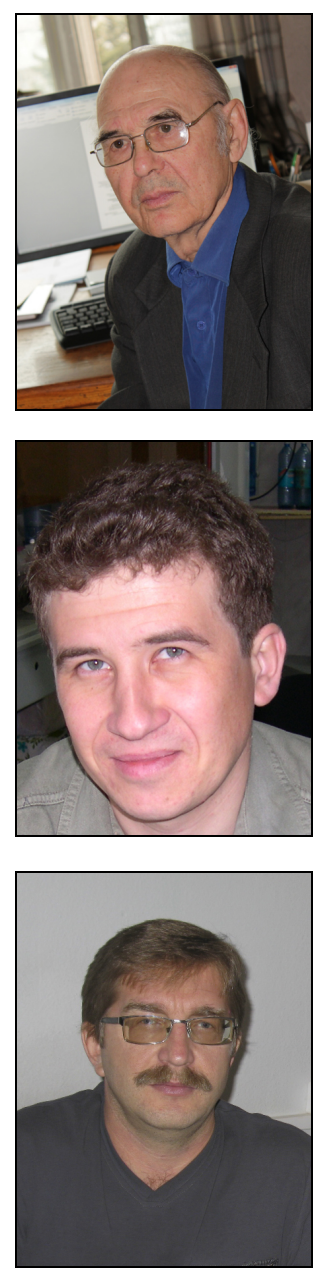

Kiselev, Aleksandr I., Doctor of Geology and Mineralogy, Lead Researcher Institute of the Earth's Crust, Siberian Branch of RAS

128 Lermontov street, Irkutsk 664033, Russia

Tel.: 8(3952)425434; \ e-mail: akiselev@crust.irk.ru

Киселев Александр Ильич, докт. геол.-мин. наук, в.н.с.

Институт земной коры СО РАН

664033, Иркутск, ул. Лермонтова, 128, Россия

Тел.: 8(3952)425434; \ e-mail: akiselev@crust.irk.ru

Ivanov, Alexei V., Doctor of Geology and Mineralogy, Lead Researcher Institute of the Earth's Crust, Siberian Branch of RAS

128 Lermontov street, Irkutsk 664033, Russia

Tel.: 8(3952)427117; e-mail: aivanov@crust.irk.ru

Иванов Алексей Викторович, докт. геол.-мин. наук, в.н.с.

Институт земной коры СО РАН

664033, Иркутск, ул. Лермонтова, 128, Россия

Тел.: 8(3952)427117; e-mail: aivanov@crust.irk.ru

Danilov, Boris S., Candidate of Geology and Mineralogy, Researcher Institute of the Earth's Crust, Siberian Branch of RAS

128 Lermontov street, Irkutsk 664033, Russia

Tel.: 8(3952)511680; e-mail: boris@crust.irk.ru

Данилов Борис Станиславович, канд. геол.-мин. наук, н.с.

Институт земной коры СО РАН

664033, Иркутск, ул. Лермонтова, 128, Россия

Тел.: 8(3952)511680; e-mail: boris@crust.irk.ru 